\title{
СИСТЕМНАЯ МОДЕЛЬ ФАКТОРОВ ПРОФЕССИОНАЛЬНОЙ УСПЕШНОСТИ СПОРТСМЕНОВ - ПРЕДСТАВИТЕЛЕЙ СПОРТА ВЫСШИХ ДОСТИЖЕНИЙ
}

Сухарева (Бакуняева) Д.С., Обознов А.А.,(Институт психологии РАН, Москва, Россия), dbakunyaeva@gmail.com,aao46@mail.ru 乙tinцuјugर्रшध шर्रu. '29.07.2019

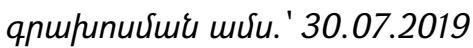

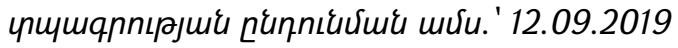

В статье приводится теоретико-эмпирическое обоснование системной модели факторов профессиональной успешности в спорте высших достижений. Модель представляет собой систему фракторов профессиональной успешности спортсменов, отражающую в сжатом виде не только процесс профессионализации, но и жизни в целом. Процесс профессионализации спортсменов-представителей спорта высших достижений рассматривается во взаимосвязанности прошлого, настоящего и будущего. Прошлое - мотивы выбора спортивной карьеры - выступает в виде причинности, настоящее - системное влияние смысложизненных ориентаций, индивидуально-типологических особенностей спортсменов и спортивной травмы на профессиональную успешность - выступает как функциональная зависимость, а будущее - планируемая длительность соревновательной активности - выступает в виде желаемых профессиональных целей.

Ключевые слова: профессиональная успешность, спорт высших достижений, смысложизненные ориентации, индивидуально-типологические особенности.

Профессиональную успешность в спорте высших достижений принято определять по ряду объективных и субъективных критериев. К объективным критериям относятся, прежде всего, показатели соревновательной активности результаты выступлений на крупнейших международных и национальных соревнованиях в течение олимпийского цикла. Кроме того, к ним относятся установленные рекорды, показатели стабильности высоких результатов, спортивный разряд или звание, рейтинг спортсменов и др. К субъективным критериям относятся самооценки спортсменов соревновательной результативности, показатели удовлетворённости самореализацией в спортивной профессии и др.

Анализ ранее проведённых исследований позволил выявить целый ряд факторов профессиональной успешности, которые могут быть объединены в непсихологические и психологические факторы. К непсихологическим фракторам относятся пол, возраст, вид спорта, спортивная травма и др. Отметим, что спортивная травма может рассматриваться не только как физическое ограничение, 
т.е. непсихологический фактор, но и как психологический «кризисный» фрактор, играющий значимую смыслообразующую роль для профессиональной успешности спортсменов (Башкиров, 1987;; Валеев, 2004; Леонов, 2012; Зинченко, 2011; Сафонов, 2012; Сопов, 2014; Blackwell, McCullagh, 1990). К психологическим факторам относятся индивидуально-типологические (Палайма, 1966; Капустин,1973; Румянцева,1975; Вяткин,1978; Hanin, 2003; Robazza, 2006 и др.), социальнопсихологические (Пуни, 1978; Ильин, 2012; Мартенс, 1997; Гулд, 2002 и др.), мотивационные (Палайм, 1966; Келишев, 1972; Пилоян, 1984; Шаболтас, 1998; Гогунов, 2002; Шумилин, 2003; Панкратов, 2015; Biddle, 1993 и др.), ценностносмысловые (Шаболтас, 1998; Горская, 1999; Румянцева, 2001; Пуни, 2002; Шумилин, 2003; Голец, 2008, Султанова, 2009, Панкратов, 2015; Ames, 1992; Biddle, 1993 и др.) характеристики спортсменов.

Цель нашего исследования состоит в разработке системной модели факторов профессиональной успешности спортсменов-представителей спорта высших достижений.

Этапы разработки системной модели. На 1-ом, теоретическом этапе обосновывалась априорная модель факторов профессиональной успешности спортсменов-представителей спорта высших достижений. Для этого выявлялось своеобразие спорта высших достижений, получившего в России официальный статус профессии в 1999 году, как особого вида профессиональной деятельности. Это своеобразие заключается в ранней профессионализации, относительной непродолжительности занятий профессиональным спортом, непрерывном нахождении профессионального спортсмена в зоне абсолютных пределов своих физических и психических возможностей, риске травматизма, повышенном внимании со стороны социума, высокой степени социальной ответственности за соревновательные результаты. Указанные особенности спортивной профессии предъявляют жёсткие требования не только к физическим, но и психическим, личностным и нравственным качествам спортсменов. Спорт высших достижений требует от них высокой выраженности мотивации достижения и целеустремлённости, осознанности и осмысленности своей деятельности, доминирования духовных, морально-нравственных ценностей, отношения к профессии как смыслу жизни [9]. Методологическими основаниями априорной модели являлись принципы системного и субъектно-деятельного подходов, общепринятых в российской психологии. Теоретическими основаниями служили: теория стремления к смыслу [10]; положения о том, что «источник» смысла жизни может быть найден человеком в будущем («цели в жизни»), настоящем («процесс жизни»), прошлом («результативность жизни»), либо на всех этапах жизни [6]; положения о смысложизненном отношении к своей профессии [3]; классификация «встроенности» жизненных смыслов в профессиональную деятельность [4]; концепция смысложизненных ориентаций [6, 11]; теоретические положения об особенностях спортивной 
деятельности [7 и др.], научные представления о профессиональной успешности [2 и др.]. В итоге, была предложена авторская априорная модель, которая представляет собой систему факторов профессиональной успешности спортсменов, опосредствованных событиями их предшествующей жизни (профессиональное прошлое) и опосредствующих их профессиональное будущее. Модель включала в качестве непсихологических компонентов пол, возраст, вид спорта, спортивная травма, а в качестве психологических - мотивы выбора спортивной карьеры, смысложизненные ориентации, личностные (индивидуально-типологические) особенности профессиональных спортсменов, профессиональные планы [1].

На 2-ом этапе разрабатывалась программа исследования для получения первичных данных, необходимых для эмпирической верификации априорной модели, проводился сбор первичных данных и их обработка. Для сбора эмпирических данных использовались: метод анализа документов (квалификационные требования, федеральные и профессиональные стандарты, официальные рейтинги спортсменов); опросники СЖО («Смысложизненные Ориентации», Леонтьев, 2000) и ИТО («Индивидуально-типологический опросник», Собчик, 2005); структурированное интервью для оценки мотивов выбора спортивной профессии и профессиональных планов спортсменов. Для оценки уровня профессиональной успешности использовалась 4-х уровневая шкала - очень высокий, высокий, средний невысокий уровень. Обследованную выборку составили 500 спортсменов-представителей спорта высших достижений обоего пола в возрасте от 15 до 39 лет. Все спортсмены входили в состав национальных сборных команд России.

На 3-ем этапе проводилась эмпирическая верификация (проверка) соответствия априорной модели полученным эмпирическим данным с помощью метода путевого анализа. Анализ путей осуществлялся с помощью программы IBMAmos 22.0 Windows. Была построена системная модель, включавшая следующие компоненты: смысложизненные ориентации «осмысленность жизни» и «процесс жизни» (опросник СЖО), индивидуально-типологические свойства «агрессивность», «экстраверсия», «ригидность» (опросник ИТО), «мотивы выбора вида спорта», «пол», «наличие травмы», «вид спорта», «профессиональная успешность», «профессиональные планы» и «планируемая длительность соревновательной активности» (рисунок). 


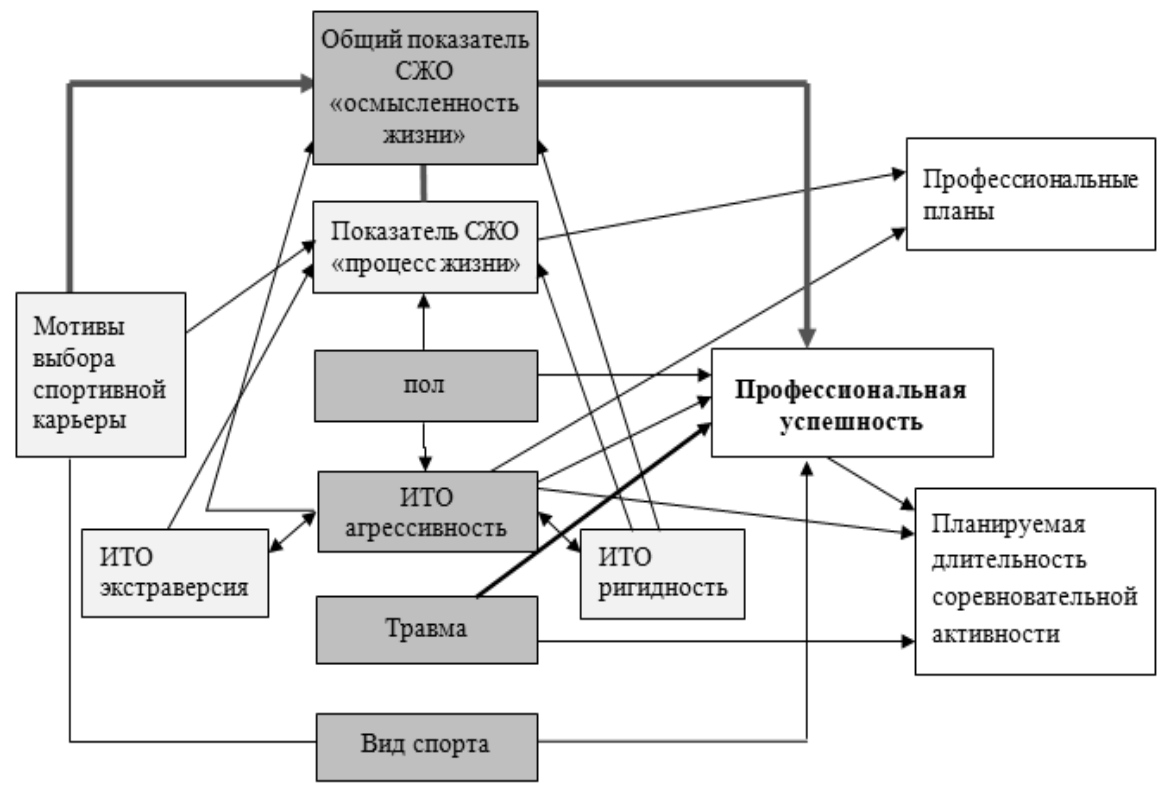

Рнсунок 1. Снстемная модель факторов професснональной успешности в спорте высших достиженнй.

- факторы, оказывающие прямое влияние; $\square$ - факторы, оказывающие опосредствованное влияние; $\longrightarrow$ наиболее сильное опосредствованное влияние (путевой коэффициент $=0,4$ );

$\longrightarrow$ наиболее сильное прямое влияние (путевой коэффициент $=0,2$ )

Как показал анализ путевых коэфффициентов, при рассмотрении прямого влияния всех независимых переменных (непсихологические и психологические факторы) на зависимую переменную («профессиональная успешность», наибольшее влияние на уровень профессиональной успешности вносит фактор «наличие травмы» $(0,2)$, а наименьший - факторы «вид спорта» $(-0,1)$, «агрессивность» $(-0,1)$ и «осмысленность жизни» $(0,1)$. При изучении опосредствованного (непрямого) влияния были получены следующие путевые коэффициенты:

«мотив выбора вида спорта» $\rightarrow$ «осмысленность жизни» $\rightarrow$ «профессиональная успешность» $=0,523^{*} 0,1=0,05$;

«процесс жизни/эмоциональная насыщенность жизни» $\rightarrow$ «осмысленность жизни» $\rightarrow$ «профрессиональная успешность» $=2,537^{*} 0,1=0,25$;

- $\quad$ полное непрямое влияние $=(0,05+0,25)=0,3$;

- $\quad$ полное каузальное влияние $=0,3+0,1=0,4$.

Было выявлено, что фрактор «осмысленность жизни» (при учете влияния на него факторов «мотивы выбора спорта» и «процесс жизни») оказывает достаточно сильное $(0,3)$ непрямое влияние на уровень профессиональной успешности спортсменов. Если рассматривать полное каузальное влияние, то влияние фактора «осмысленность жизни» на уровень профессиональной успешности становится ещё сильнее и составляет 0,4. 
Эмпирическая верификация априорной модели в целом подтвердила значимость прямого влияния на уровень профессиональной успешности смысложизненных ориентаций и индивидуально-типологических особенностей личности спортсменов. При этом эмпирическое подтверждение получило влияние на уровень профессиональной успешности не всех, а только некоторых видов смысложизненных ориентаций (эмоциональная насыщенность жизни/процесс жизни и осмысленность жизни) и индивидуально-типологических особенностей (агрессивность, экстраверсия и ригидность) личности профессиональных спортсменов. Влияние остальных видов смысложизненных ориентаций и индивидуальнотипологических особенностей личности на уровень профессиональной успешности не подтвердилось.

Заключение. Таким образом, результаты путевого анализа показали, что при раздельном и системном учёте психологических и непсихологических факторов сила влияния на уровень профессиональной успешности каждого из них выражается в разных значениях путевого коэффициента. Это означает, что каждый изолированно рассматриваемый фактор (будь он психологический или непсихологический), проявляющий значимость для профессиональной успешности спортсменов, может частично или полностью утратить эту значимость, при его системном рассмотрении, т.е. во взаимодействии с другими факторами. Например, значимое влияние на уровень профессиональной успешности фактора «возраст», установленное при его изолированном рассмотрении, оказывается утраченным при системном рассмотрении. Данный результат лишний раз доказывает, что при изучении факторов профессиональной успешности вообще и в спорте высших достижений, в частности, необходимо опираться на методологию системного подхода.

Результаты путевого анализа позволяют утверждать, что мотивы ранее состоявшего выбора спортивной карьеры (профессиональное прошлое спортсменов) опосредствованно, через смысложизненные ориентации, влияют на их профессиональную успешность в настоящем, а успешность, в свою очередь, опосредствует планируемую длительность соревновательной активности (профессиональное будущее). Показано, что для достижения пика мастерства в спорте высших достижений необходимо изначально руководствоваться внутренними мотивами выбора спортивной карьеры, быть удовлетворённым процессом жизни, иметь высокий уровень осмысленности жизни, высокую выраженность экстраверсии, стеничности и ригидности. Такое сочетание факторов, как показали результаты путевого анализа, в свою очередь, будет способствовать формированию позитивной картины своего дальнейшего профессионального будущего по завершению соревновательной активности [1].

Предложенная системная модель факторов профессиональной успешности, в сжатом виде отражающая временную структуру процесса профессионализации в спорте высших достижений, может служить теоретической основой для 
профессионального отбора в национальные сборные, а также прогнозирования соревновательной успешности в спорте высших достижений.

\section{Литература}

1. Бакуняева Д.С. Смысложизненные ориентации в системе факторов профессиональной успешности спортсменов - представителей спорта высших достижений: дисс. канд. психол. наук : 19.00.03.- Москва, 2018.- 215 с.

2. Бодров В.А. Психология профессиональной пригодности: учебное пособие для вузов/ В.А.Бодров.- М.: ПЕР СЭ, 2001. - 511 с

3. Завалишина Д.Н. Методологический аспект смысложизненной ценности профессионального труда// Смысл жизни и акме// Материалы VIII - X симпозиумов.- Часть 1.- 2004.- С.168 - 172

4. Карпинский К. В. Смысл жизни и жизненный смысл профессии// Вестник ТГУ.-№6.- 2010.- С.147 - 154.

5. Климов Е.А. Психология профессионала/ Е.А.Климов.- М.: Изд-во «Институт практической психологии», Воронеж: НПО «МО-ДЭК», 1996- 400 с.

6. Леонтьев Д. А. Тест смысложизненных ориентаций / Д.А. Леонтьев. - 2-е изд. - М.: Смысл, 2000.- 18с.

7. Сафонов В.К. Психология в спорте: теория и практика / Сафонов В.К.СПб: Издательство С.- Петербургского университета, 2013.- 232с.

8. Собчик Л.Н. Психология индивидуальности. Теория и практика психодиагностики/ Л.Н.Собчик. - СПб.: 2005.- 624с.

9. Стамбулова Н.Б. Психология спортивной карьеры: дисс. ... д-ра психол. наук: 19.00.13/ Стамбулова Наталья Борисовна.- СПб., 1999.- 417 с.

10. Франкл В. Человек в поисках смысла: сборник / пер. с англ. и нем. / Общ. ред. Л.Я. Гозмана и Д.А. Леонтьева; вст. ст. Д. А. Леонтьева. - М.: Прогресс,1990. - 368c.

11. Чудновский В.Э., Бодалев А.А., Вайзер Г.А., Вахромов Е.Е., Карпова Н.Л., Суворов А.В. Роль смысложизненных ориентации и акме в профессиональной деятельности (опыт теоретико-экспериментального исследования) // Психологический журнал. - 2004.-Т.25.- №1.- С.34 - 48.

\section{THE SYSTEM MODEL OF THE PROFESSIONAL SUCCESS FACTORS OF THE ATHLETES IN HIGH PERFORMANCE SPORT}

Sukhareva D.S., Oboznov A.A. (Institute of Psychology of the Russian Academy of Sciences, Moscow, Russia)

In this article, the authors present a theoretical substantiation of the system model of the professional success factors of the athletes in high performance sport, as well as 
its empirical confirmation. The model is a system of factors of professional success of athletes, reflecting in its essence not only a compressed model of professionalization, but also a compressed model of life in general. The development of an athlete in high performance sport, is seen in the determination of past, present and future; where the past is in the form of conditions, causality (motives for choosing a sports career), the present is characterized by functional dependence (connection of life-sense orientations and individual-typological features, sports injury and the influence of these factors on professional success), the future is in the form of goals, the beginnings of the future (planned duration of competitive activity, professional and life plans).

Key words: professional success, high performance sport, life meaningful orientations, individual and typological features, factors. 